\title{
Abortion in women partners of inmates: prevalence and associated factors
}

\author{
Aborto em mulheres parceiras de apenados: \\ prevalência e fatores associados \\ Aborto en mujeres de reclusos: \\ prevalencia y factores asociados

\section{Débora Cristina Martins ${ }^{a}$ Giordana Maronezzi da Silva ${ }^{a}$ Beatriz Maria dos Santos Santiago Ribeiro ${ }^{b}$ Giovanna Brichi Pesce ${ }^{c}$ Carlos Alexandre Molena Fernandes ${ }^{c}$}

How to cite this article: Martins DC, Silva GM, Ribeiro BMSS, Pesce $G B$, Fernandes CAM. Abortion in women partners of inmates: prevalence and associated factors. Rev Gaúcha Enferm. 2021;42:e20200429. doi: https://doi. org/10.1590/1983-1447.2021.20200429
- Universidade Estadual de Maringá (UEM), Centro de Ciências da Saúde. Programa de pós-graduação em Enfermagem. Maringá, Paraná, Brasil.

${ }^{\mathrm{b}}$ Escola de Enfermagem de Ribeirão Preto (USP), Programa de Pós-Graduacão de Enfermagem em Saúde Pública. Ribeirão Preto, São Paulo, Brasil.

Universidade Estadual do Paraná (UNESPAR). Campus Paranavai. Paranavaí, Paraná, Brasil.

\section{ABSTRACT}

Objective: To analyze factors and behaviors associated with the prevalence of abortion in female partners of prisoners.

Methods: Descriptive, cross-sectional study with a quantitative approach carried out with 349 women of inmates in three penitentiaries in the State of Paraná. For data collection, it was used validated instrument BSSB - Brazilian Study on Sexual Behavior. Descriptive analyzes were processed, and through the Chi-square test, the occurrence of abortion and the researched variables were associated.

Results: (38.3\%) of the women reported abortion throughout their lives, there was an association between women under the age of $30(p=<0.001)$, who reported smoking ( $p=<0.044)$, not using condoms $(p=<0.001)$, who suffered sexual violence $(p=<0.050)$ and who reported a diagnosis of Sexually Transmitted Infections $(p=<0.001)$.

Conclusion: The present study showed associated factors for high prevalence of abortion in women partners of inmates. Abortion is considered an important public health problem and needs to be treated with priority by public health policies in different population groups.

Keywords: Abortion. Women's health. Vulnerable populations.

\section{RESUMO}

Objetivo: Analisar fatores e comportamentos associados à prevalência de aborto em mulheres parceiras de apenados. Métodos: Estudo descritivo, transversal de abordagem quantitativa realizado com 349 mulheres de apenados em três penitenciárias no Estado do Paraná. Para coleta dos dados foi utilizado instrumento validado ECOS - Estudo de Comportamento Sexual no Brasil. Processaram-se análises descritivas, e através de teste Qui-quadrado associou-se a ocorrência de aborto e as variáveis pesquisadas. Resultados: (38,3\%) das mulheres referiram aborto ao longo da vida, houve associação entre mulheres com idade inferior a 30 anos ( $p=<0,001)$, que referiram tabagismo $(p=<0,044)$, não uso de preservativo $(p=<0,001)$, que sofreram violência sexual $(p=<0,050)$ e que relataram diagnóstico de Infecções Sexualmente Transmissíveis $(p=<0,001)$.

Conclusão: 0 presente estudo evidenciou fatores associados para elevada prevalência de aborto em mulheres de apenados. 0 aborto é considerado importante problema de saúde pública e necessita ser tratado com prioridade pelas políticas públicas de saúde em diferentes grupos populacionais.

Palavras-chave: Aborto. Saúde da mulher. Populações vulneráveis.

\section{RESUMEN}

Objetivo: Analizar factores y comportamientos asociados a la prevalencia del aborto en las parejas femeninas de los presos.

Métodos: Estudio descriptivo, transversal con enfoque cuantitativo realizado con 349 mujeres presas en tres cárceles del estado de Paraná. Para la recolección de datos, se utilizó un ECOS - Estudio de Comportamiento Sexual en Brasil validado. Se procesaron análisis descriptivos, mediante la prueba de chi-cuadrado, se asociaron la ocurrencia de aborto y las variables estudiadas.

Resultados: (38.3\%) de las mujeres reportaron aborto a lo largo de su vida, hubo asociación entre mujeres menores de 30 años ( $p$ $=<0.001)$, quienes reportaron fumar ( $p=<0.044)$, no usar condón $(p=<0.001)$, que sufrieron violencia sexual $(p=<0.050)$ y reportaron un diagnóstico de Infecciones de Transmisión Sexual ( $p=<0.001)$.

Conclusión: El presente estudio mostró factores asociados a la alta prevalencia de aborto en mujeres condenadas. El aborto se considera un problema importante de salud pública y debe ser tratado con prioridad por las políticas de salud pública en diferentes grupos de población.

Palabras clave: Aborto. Salud de la mujer. Poblaciones vulnerables. 


\section{口INTRODUCTION}

Women of inmates, in their daily lives, expose themselves to a different life routine in relation to other women, as they end up being doubly penalized and stigmatized by society. It is noticeable that the prison environment provides health risks, because through the incarceration of the partner, changes in lifestyle can occur that allow them more exposure to risk factors, leaving them more vulnerable to diseases and health-related complications ${ }^{(1)}$, such as abortion.

Thus, these women tend to be more exposed to risk factors such as smoking, alcoholism, use of illegal drugs and also some types of sexual behavior that can result in Sexually Transmitted Infections (STI) and unwanted pregnancy ${ }^{(2-3)}$. The lack of family planning together with these risk factors in a vulnerable population can lead to the occurrence of spontaneous abortion or even induced abortion ${ }^{(3)}$.

Abortion is a relevant issue in public health, which in most cases has been considered an unsafe practice in which it is associated with maternal mortality and the high number of hospital admissions in the Unified Health System (Sistema Unico de Saúde -SUS), affecting the health of young women and those from disadvantaged social strata, as in the case of women of inmates ${ }^{(3)}$.

The World Health Organization (WHO) clinically defines abortion as the interruption of pregnancy until the $22^{\text {nd }}$ week of gestational age, with the product of conception weighing less than 500 grams. Abortion is estimated as unsafe when performed in precarious or inadequate sanitary conditions and also when performed by untrained people ${ }^{(4-5)}$. Every year, about 20 million abortions are performed worldwide under risky conditions, considering the poor quality of the procedure(5).

Approximately $95 \%$ of these abortions are performed in developing countries, which persist in maintaining strict and inept laws that hinder abortion ${ }^{(5)}$. As a result, up to $25 \%$ of maternal mortality comes directly from unsafe abortion, leading to the death of nearly 67,000 women each year, which can be considered preventable deaths. Evidence is decisive in confirming the ineffectiveness of the prohibition of abortion as a way to avoid its practice, facing the dramatic effects of the legal prohibition on the deaths of women of childbearing age $\mathrm{e}^{(5-6)}$. Worldwide, $40 \%$ of all pregnancies are unintentional and around 50\% of these unwanted pregnancies end in abortion ${ }^{(7)}$. Unsafe abortion contributes a lot to the high risk of maternal mortality and morbidity in developing countries ${ }^{(8)}$.
Studies from Brazilian National Abortion Survey 2016 (PNA 2016) indicate that abortion among Brazilian women has gradually increased over the years. The main objective of this study was to estimate the magnitude of this practice in Brazil, showing that from the 2,002 literate women between 18 and 39 years old interviewed by the PNA 2016, $13 \%$ (251) have already had at least one abortion and in the age group of 35 to 39 years, and $18 \%$ of women have had an abortion ${ }^{(5)}$.

It is important to highlight that vulnerability and unwanted pregnancies are heavily influenced by access or lack of access to contraceptive methods, in addition to exposure to unwanted sex, sexual violence and early marriage ${ }^{(6)}$. It is still necessary to consider that some sociodemographic characteristics (marital status, age, schooling, family income) are established as one of the possible causes of abortion in the face of an unplanned pregnancy ${ }^{(6-7)}$.

In Brazil, most scientific research about abortion in the field of public health has been carried out with women hospitalized in the public health network ${ }^{(3)}$. However, there are still gaps and few investigations in Brazil about abortion experiences in women from different social categories, especially those who are more vulnerable ${ }^{(3,6)}$, as is the case of women partners of inmates.

The prison environment offers physical and psychological risks and the transmission of infectious diseases due to the heterogeneity of incarcerated subjects ${ }^{(1,9)}$. Some factors related to this dimension of vulnerability are the lack of access to information and educational activities on contraceptive methods suitable for vulnerable populations, the ways of transmission and prevention of Sexually Transmitted Infec-

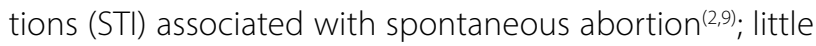
motivation or personal awareness to assess and understand the risks of unwanted pregnancy and sexual violence that can be associated with induced abortion; little ability to adopt preventive measures, including safer lifestyle habits such as smoking cessation and other drugs during pregnancy and for future life $e^{(4,8)}$.

In the case of women of inmates, it is necessary to interact with the National Policy of Comprehensive Health Care to People Deprived of Liberty in the Prison System (Política Nacional de Atenção Integral à Saúde das Pessoas Privadas de Liberdade no Sistema Prisional - PNAISP) in the prison system, which has as one of its objectives the importance of thinking about the health/disease/care process beyond the individual, thus involving an expanded network, such as the family and sociability networks ${ }^{(7,10)}$. 
Given the exposed and based on the hypothesis about the condition of vulnerability of women of inmates, we are faced with the following question: health behaviors, sexual behaviors, and unwanted pregnancy are risk factors that may be associated with the prevalence of abortion in women of inmates? Based on this information and seeking to identify differences in the prevalence of abortion in this population, this study aimed to analyze the factors associated with the prevalence of abortion in women partners of inmates.

\section{$\square$ METHODS}

This is a cross-sectional quantitative study. The study was carried out with 349 women of inmates in the three largest penitentiaries in the State of Paraná, from January to July 2016. For the sampling of this study, the three largest penitentiaries in the State of Paraná with a penal system of closed regime with male inmates were selected by convenience sample, with penitentiary 1 belonging to the $1^{\text {st }}$ Regional, located in a municipality in the southern region of the State of Paraná, its population. Penitentiary 2 is located in the North region of the State, is part of the $4^{\text {th }}$ Regional and penitentiary 3, located in the Southwest region of the State, is part of the $7^{\text {th }}$ Regional|(11).

According to reports from prison officers and the secretariat of the Paraná Department of Public Security, approximately $80 \%$ of inmates receive visits from their partners and are open to intimate visits, through monthly schedule, due to the high demand for visits ${ }^{(11)}$. Penitentiary 1 receives around 900 women, penitentiary 2 receives around 600 women and penitentiary 3 receives around 700 women $(n=2,200)$.

In view of the sample size, statistical analysis was performed by proportional stratification, totaling a sample of 366 women for the research, considering a confidence level of $95 \%$, maximum desired error of $5 \%$, proportion in the population of $50 \%$ and increase of $10 \%$ for possible losses, distributed in the three penitentiaries of the State. Thus, participated in the research, 136 women from penitentiary 1, 74 women from penitentiary 2 and 139 women from penitentiary 3 . The 366 questionnaires were revised one by one; nine were excluded for containing only the completed identification form, eight for presenting more than $20.0 \%$ of the questions not completed in the instrument Brazilian Study on Sexual Behavior (BSSB), totaling 349 valid questionnaires ( $95 \%$ of the calculated sample).

This study included women partners of inmates, aged over 18 years, who had been making intimate visits to their partners for more than six months and who agreed to participate in the research. Women with other degrees of kinship with the inmates (mothers, daughters and others) were excluded, as well as those who, at the time of the interview, were under the influence of alcohol and other illicit drugs.

Women were randomly selected on the days and times scheduled for intimate visits to their partners in penitentiaries. Data collection was carried out in a waiting yard in the penitentiaries, while the women waited to enter the visits, aiming at the privacy of the interviewees and ensuring the total confidentiality of their information.

Data collection took place from January to July of 2016. It was used a semi-structured instrument Brazilian Study on Sexual Behavior (BSSB), model II, with 38 questions, which was adapted for field research only for this population of women. The BSSB questionnaires were developed by Abdo and his researchers in three models - models I, II and III. Model II was applied and modified with guiding questions to this population of women of inmates, with a sociodemographic profile, considering that the merit of this instrument, for this research, is not to stick only to data on risky sexuality, but to portray different aspects and offer a profile on the current and past sexual behavior of the studied population ${ }^{(12)}$.

This instrument, in its first part, seeks to portray the profile and sociodemographic characteristics, as well as the tracking of risk factors related to lifestyle (alcohol intake, smoking, use of illicit drugs and practice of physical activity). In the second part, it seeks to identify number of pregnancies, occurrence of abortion throughout life, diagnosis and treatment of $\mathrm{STI}$, as well as types of sexual behavior (age at first sexual intercourse, number of partners in the last 12 months, sex under the influence of alcohol, sex under the influence of drugs, sex for money, sexual violence) ${ }^{(12)}$. Answers were self-reported, if yes or no.

The information related to the collected data was entered into an Excel for Windows 2007 spreadsheet and then statistically analyzed using the Statistical Package for Social Sciences (SPSS), version 20. The Kolmogorov Smirnov test, graphical methods and standardized values of asymmetry and kurtosis ( $\pm 2 Z$ ) to identify the normality of the data. To characterize the sample, descriptive statistics expressed through absolute and relative frequency were used for categorical variables, median and interquartile range for continuous variable (beginning of sexual life), due to its non-parametric distribution.

To verify differences in the proportions between the dependent variable (Abortion) and the independent variables, the Chi-Square test was adopted. In $2 \times 2$ contingency tables Yates Continuity Correction was performed. 
Multivariate Logistic Regression was used to determine the Odds Ratio (OR), and the respective Confidence Intervals (CI) (95\%), in order to analyze the association between the occurrence of abortion with the independent variables. For the inclusion of independent variables in the multivariate model, the criterion was an association level of $p \leq 0.20$ with the dependent variable, by the Chi-square test, presented later in the model $p \leq 0.05$.

The research was authorized by the three penitentiary institutions and, later, by the National Penitentiary Department (Departamento Penitenciário Nacional - Depen) of Paraná. As this is a research that involves human beings, the ethical and legal precepts regulated by resolution No. $466 / 2012$, of the CNS - MS and the authorization of the Permanent Committee on Ethics in Research Involving Human Beings (CETI-FAP) of the Faculdade de Apucarana (FAP), obtaining the Certificate of Presentation for Ethical Appraisal (CAAE) number 49827315.4.0000.5216 and opinion number 1.330.747. The request for participation in the study was accompanied by two copies of the Free and Informed Consent Form (FICF), in which the participants were notified about the purposes of the research, type of desired participation and the interview methodology, with one copy remaining with the respondent and one way with the researcher.

\section{DESULTS}

It was identified that, of the total sample ( $n=349), 39.0 \%$ $(n=136)$ were from penitentiary $1 ; 39.8 \%(n=139)$, from penitentiary 2 ; and $21.2 \%(n=74)$ from penitentiary 3 . It was also noted that most women (51.9\%) were aged between 20 and 29 years. For race/color, white and brown skin were the most mentioned, with $41.5 \%$ and $42.1 \%$, respectively. Regarding marital status, $49.0 \%$ reported having a partner, that is, living with their "partner" without being officially married, 21.2\% were single and $29.8 \%$ were married. The number of children each woman had was also evaluated, with more than half of the women (53.3\%) having one or two children. Most women (59\%) reported not working outside the home. As for schooling, $73.6 \%$ of women had not completed high school and $6.3 \%$ of women reported having completed higher education. Finally, the median age at which women began their sexual life was 14 years.

InTable 1, it is observed that the total number of women who reported an abortion is 134 women, corresponding to $38.3 \%$. The proportions of the categories of independent variables with the proportion of the dependent variable abortion are also presented.
There were statistically significant differences regarding the variables associated with the occurrence of abortion throughout life, which were: age under 30 years $(p<0.001)$, risk behavior such as being a smoker $(p=<0.044)$, having some type of addiction ( $p=<0.049$ ), sexual behavior such as not using condoms $(p=<0.001)$, sexual violence $(p=<0.050)$ and STI diagnosis $(p=<0.001)$.

In Table 2, through the crude logistic regression analysis it was sought to show in isolation the odds according to the categories of variables regardless of having an abortion throughout life, and the associated variables were the same as those associated by the analysis of Chi-square test.

For women who confirmed they were smokers, the odds were $1.6(1.1-2.5)$; having other addictions, 1.6 (1.1 - 2.4) times more likely, those who reported sexual violence 1.6 $(1.1-2.6)$ respectively, of having had an abortion throughout their lives.

In the adjusted regression analysis, the associated variables were: women under the age of 30 years were 1.9 (1.2 - 3.0) times more likely to have had an abortion, those who denied using condoms $2.1(1.3-3.4)$ times more likely, women who reported diagnosis and treatment of STI $2.4(1.3-4.1)$.

\section{DISCUSSION}

The results of this study show a high prevalence of abortion in women partners of inmates, as over a third of the sample (38\%) of the study's collaborators mentioned having had an abortion, and from these more than 55\% are women under 30 years old who reported having abortion history. Furthermore, the data obtained also showed the relationship between abortion in women of inmates and the consumption of tobacco and other drugs, in which such variables significantly increased the chances of this occurrence in the investigated population.

It is observed is a very significant rate of abortion among this population of women of inmates, considering that the study referring to the Brazilian National Abortion Survey (PNA 2016) shows that the abortion rate in different regions ranges from $6 \%$ to $18 \% \%^{(5)}$. It is noteworthy that when we study specific vulnerable populations, we understand these statistical differences, given the influence of social and environmental problems $s^{(6)}$. It is important to highlight that this complication is already recognized as prevalent among the female audience, considering that, according to the PNA 2016, abortion is common among Brazilian women. From the 2,002 literate women between 18 and 39 years old interviewed by the PNA 2016, 13\% (251) have already suffered at least one abortion ${ }^{(5)}$. 
Table 1 - Distribution of the population of women partners of inmates who reported abortion and factors associated with abortion complications throughout life. Penitentiaries 1, 2 and 3, Paraná (PR), Brazil, 2016 ( $n=349)$

\begin{tabular}{|c|c|c|c|c|c|c|}
\hline \multirow{2}{*}{\multicolumn{2}{|c|}{ Variables }} & \multicolumn{2}{|c|}{ Total } & \multicolumn{2}{|c|}{ Abortion + } & \multirow{2}{*}{ p-value } \\
\hline & & $\mathbf{n}$ & $(\%)$ & $\mathbf{n}$ & $(\%)$ & \\
\hline \multicolumn{2}{|l|}{$\begin{array}{l}\text { Women who reported abortion } \\
\text { troughout life }\end{array}$} & 349 & 100 & 134 & 38.3 & \multirow{3}{*}{$0.001^{*}$} \\
\hline \multirow{2}{*}{ Age } & $<30$ years & 231 & 66.2 & 79 & 55.6 & \\
\hline & $\geq 30$ years & 118 & 33.8 & 55 & 32.9 & \\
\hline \multicolumn{7}{|c|}{ Associated Behaviors (Addictions) } \\
\hline \multirow{2}{*}{ Alcohol } & Yes & 33 & 9.5 & 19 & 13.4 & \multirow[t]{2}{*}{0.059} \\
\hline & No & 316 & 90.5 & 123 & 86.6 & \\
\hline \multirow{2}{*}{ Cigarette } & Yes & 185 & 53.0 & 85 & 59.9 & \multirow[t]{2}{*}{$0.044^{*}$} \\
\hline & No & 164 & 47.0 & 57 & 40.1 & \\
\hline \multirow{2}{*}{ Drugs } & Yes & 51 & 14.6 & 27 & 19.0 & \multirow[t]{2}{*}{0.076} \\
\hline & No & 298 & 85.4 & 115 & 81.0 & \\
\hline \multirow{2}{*}{ Has any addiction } & Yes & 193 & 55.3 & 88 & 62.0 & \multirow[t]{2}{*}{$0.049^{*}$} \\
\hline & No & 156 & 44.7 & 54 & 38.0 & \\
\hline \multicolumn{7}{|l|}{ Sexual Behavior } \\
\hline \multirow{2}{*}{ Partners/12 months } & 1 & 207 & 59.3 & 81 & 57.0 & \multirow[t]{2}{*}{0.546} \\
\hline & $>1$ & 142 & 40.7 & 61 & 43.0 & \\
\hline \multirow{2}{*}{ Use condom } & Yes & 151 & 43.3 & 107 & 51.7 & \multirow[t]{2}{*}{$<0.001^{*}$} \\
\hline & No & 198 & 56.7 & 100 & 48.3 & \\
\hline \multirow{2}{*}{ Sexual violence } & Yes & 111 & 31.8 & 54 & 38.0 & \multirow[t]{2}{*}{$0.050^{*}$} \\
\hline & No & 238 & 68.2 & 88 & 62.0 & \\
\hline \multirow{2}{*}{ Money for sex } & Yes & 79 & 22.6 & 39 & 27.5 & \multirow[t]{2}{*}{0.098} \\
\hline & No & 270 & 77.4 & 103 & 72.5 & \\
\hline \multirow{2}{*}{ Alcohol effect } & Yes & 212 & 60.7 & 91 & 64.1 & \multirow[t]{2}{*}{0.344} \\
\hline & No & 137 & 39.3 & 51 & 35.9 & \\
\hline \multirow[t]{2}{*}{ Drug effect } & Yes & 71 & 20.3 & 35 & 24.6 & \multirow[t]{2}{*}{0.129} \\
\hline & No & 278 & 79.7 & 107 & 75.4 & \\
\hline \multicolumn{7}{|l|}{ STIs } \\
\hline \multirow{2}{*}{ Diagnosis } & Yes & 147 & 42.2 & 66 & 46.5 & $<0.001^{*}$ \\
\hline & No & 201 & 57.8 & 76 & 53.5 & \\
\hline
\end{tabular}

Source: Research data, 2016

Abortion + - Have had an abortion; $p-p$ value 
Table 2 - Distribution of factors associated abortion complications throughout life in the population of women partners of inmates, measured using Logistic Regression. Penitentiaries 1, 2 and 3, Paraná (PR), Brazil, 2016 ( $n=349)$

\begin{tabular}{cccc} 
Variables & & Crude Odds Ratios & Adjusted Odds Ratios \\
\cline { 3 - 4 } & & $(\mathbf{C l}$ 95\%) & (CI 95\%) \\
\hline Age & $<30$ years & 1 & 1 \\
& $\geq 30$ years & $2.2(1.4-3.5)^{*}$ & $1,9(1.2-3.0)^{*}$
\end{tabular}

Associated Behaviors (Addictions)

$\begin{array}{llc}\text { Alcohol } & \text { No } & 1 \\ & \text { Yes } & 2.1(1.0-4.4) \\ \text { Cigarette } & \text { Yes } & 1 \\ & \text { No } & 1.6(1.1-2.5)^{*} \\ \text { Drugs } & \text { Yes } & 1 \\ & \text { No } & 1.8(1.0-3.3) \\ \text { Has any addiction } & \text { Yes } & 1\end{array}$

\section{Sexual Behavior}

Partners/12 months

Yes $\quad 1.6(1.1-2.4)^{*}$

$\begin{array}{lccc} & \text { Yes } & 2.4(1.5-3.7)^{*} & 2.1(1.3-3.4)^{*} \\ \text { So } & \text { Yes } & 1 & 1 \\ \text { Sexual violence } & \text { No } & 1.6(1.1-2.6)^{*} & - \\ \text { Money for sex } & \text { Yes } & 1 & - \\ \text { Alcohol effect } & \text { No } & 1.6(1.0-2.6) & - \\ & \text { Yes } & 1 & - \\ \text { Drug effect } & \text { No } & 1.3(0.8-2.0) & -\end{array}$

STIS

Diagnosis

No

1

1

$\begin{array}{lll}\text { Yes } & 2.5(1.5-4.4)^{*} & 2.4(1.3-4.1)^{*}\end{array}$

Source: Research data, 2016

OR - odds ratio; (195\% - 95\% confidence interval adjusted for variables with $p<0.05$ 
Also as a consequence of abortion, maternal mortality may be a complication, according to data from the Mortality Information System (SIM), which shows that between the years 2006 to 2015, deaths as a result of abortion were more frequent in the age group of 20 -29 years in Brazil. In 2007 alone, the 30-39 age group recorded a higher number of deaths, totaling 770 maternal deaths in Brazil(3). Unspecified abortion, that is, abortion without identifying whether it was self-inflicted or spontaneous, remained as the most frequent underlying cause among deaths due to abortion in the period evaluated ${ }^{(3)}$.

It must be considered that, in Brazil, there is a lack of epidemiological studies on unsafe abortion ${ }^{(3)}$, especially in vulnerable, low-income populations with social problems, in which the severity of abortion is greater in maternal morbidity and mortality rates, and where is an intense need to consider the issue of preventive family planning and also the prevention of STIs to avoid abortion ${ }^{(8,13)}$. Some studies claim that abortion is associated with social inequalities, difficulties in accessing health services and information, low schooling ${ }^{(3,6,14)}$, in addition to modifiable risk factors such as smoking, alcoholism, use of drugs, as well as assistance in family planning and prevention of STIS, as some may also result in abortion ${ }^{(13,15)}$.

Considering the harmful effects of cigarettes during pregnancy, it is understood that the fetus is a passive smoker and anyone who inhales cigarette smoke involuntarily in an air environment is a highly vulnerable individual, at a risk stage in relation to its development ${ }^{(16-17)}$. The woman who smokes during pregnancy exposes her fetus not only to the elements of the cigarette smoke that crosses the placenta, but also to adulterations in placental oxygenation and metabolism, and to secondary changes in her own metabolism leaving the placental blood flow compromised and as a consequence the result of this is the reduction in uteroplacental perfusion and the conclusive poor oxygenation and fetal nutrition, which can result in a spontaneous abortion that could be avoided if there was no use of tobacco during pregnancy ${ }^{(16-18)}$.

Among the findings of this research, attention is drawn to the association between the occurrence of abortion among women who reported being smokers, in addition to the fact that smoking may also directly contribute to the appearance of other chronic diseases such as hypertension, heart disease and chronic respiratory diseases, as these women grow old ${ }^{(16)}$. Connected to this risk factor, we found that more than half of the study population (53.13\%) of the women of inmates were smokers. In the association between smoking and abortion, we found that $59.9 \%$ of women who reported having an abortion were also smokers. Importantly, this research found that the chance of a smoker woman to have an abortion is 1.6 more compared to a non-smoker woman.

Populations of vulnerable women who smoke and are pregnant should be considered a priority by health teams for smoking cessation during gestational period ${ }^{(16-18)}$, as tobacco has more than 4,000 substances present in its composition, but many are not well known, and it is known that the toxic substances found in cigarettes almost all affect fetal development, causing abortion in the first trimester of pregnancy, fetal malformation, premature birth, low birth weight and other pathologies with respiratory and cardiac impairments and also allergies ${ }^{(16)}$

Also, as observed in the results, women of inmates who reported not using condoms during sexual intercourse corresponded to $51.7 \%$ of those who have had an abortion. We consider that Sexually Transmitted Infections (STIS) can also bring abortion as consequences ${ }^{(14,19)}$ however in the present study we cannot state such result, since the antecedents of the occurrence of abortion were not researched, however, the habit of not using a condom is significant to the result found ${ }^{(8)}$.

According to a study carried out with 358 young migrants working in entertainment venues in China, to find out the prevalence and factors associated with a history of abortions and sexually transmitted infections, it was found that almost $60 \%$, or 213 women among single women and married women reported a history of abortion throughout life associated with ST/(13). The same study found that $89.3 \%$ of women who did not use condoms during their first sexual intercourse also reported having had an abortion and that abortion associated with not using contraceptives during the first sex resulted in 2.29 times more chance of woman in causing an abortion due to an unwanted pregnancy or suffering a spontaneous abortion as a result of some type of $\left.S T\right|^{(13)}$.

Data that corroborates this study with women of inmates, as women who reported abortion throughout their lives and also STI add up to $46.6 \%$ with a significance level of $(p=<0.001)$, and those who reported not using condoms add up to $48.3 \%$. also with a significance level of $(p=<0.001)$. It should be considered that in the multivariate regression analysis, women who did not use condoms during sexual intercourse were 2.5 times more likely to have suffered or induced abortion, and women who reported a history of STI had 2.4 times more likely to have abortion as an outcome of obstetric complications.

In another qualitative study carried out with women of inmates in a prison in a municipality located in the north of the State of Paraná, some of these women reported the need to be involved with other partners due to financial need, 
that is, sex for money, and also due to emotional need. In this same study, some women reported not using condoms because they trusted their partners to undergo periodic tests in the prison environment, but most women reported having already undergone STI treatment ${ }^{(20)}$.

As verified in the results, it was identified that $38 \%$ of women who reported having suffered sexual violence also had an abortion throughout their lives, sexual violence contributes 1.6 more chances of abortion in these women. It is important to emphasize that sexual violence is a global public health problem and its main victims are women ${ }^{(21)}$. Women who suffer sexual violence are more likely to develop psychosomatic illnesses, suicide attempts and use of psychoactive substances; besides being more predisposed to contract Sexually Transmitted Infections (STI) and to have an unwanted pregnancy ${ }^{(13,21-22)}$. Thus, we can consider that there are several factors associated with sexual violence that can lead to abortion, whether spontaneous abortion or induced abortion is legal or not ${ }^{(21,23)}$.

In relation to the care of victims of sexual violence and abortion, a study showed that the constant lack of knowledge of Brazilian legislation in analogy to abortion among health professionals, a situation that favors the appearance of inappropriate attitudes towards women and hinders access to legal termination of pregnancy, giving their private opinions with unnecessary judgments without taking into account the reality experienced by these women ${ }^{(23)}$. The search for help related to sexual violence happens only after the discovery of pregnancy, and pregnancy appeared as a denouncing factor of sexual violence due to the desire to have an abortion or to undergo prenatal care $\mathrm{e}^{(21,23)}$.

Visibly, there are social and political resistances underlying the issue of dealing with violence against women and abortion and in the implementation and adequacy of care services ${ }^{(21,24)}$. Abortion is a controversial issue that faces religious barriers, political obstacles and ethical conflicts and probably the implementation of appropriate and efficient care that collides with these social issues and public health policies $^{(22-23)}$. In this context, it is important to highlight that health professionals, especially nurses, have an important role in health guidance and education in the vulnerable population ${ }^{(17,24)}$ as women of inmates and the inmates themselves, as there are several paradigms to be faced with this population ${ }^{(9)}$.

It is also highlighted here that this is one of the rare studies with this population. It is recommended the expansion and development of future studies that can contribute to better scientific evidence with the population of women of inmates in Brazil, except that there are a large number of women in penitentiaries and prisons in Brazil who frequently visit their partners and suffer from risk factors and behaviors that can lead to complications of abortion and other health problems.

Given the implications of this study, it is noticeable that the promotion, prevention and nursing interventions strategies in relation to reproductive health, in a prison environment, must encompass the complexity of the particularities experienced by women of inmates. It is important to know and group the contexts of environmental, social and cultural vulnerabilities in order to identify risk exposures, different lifestyles and behaviors in this population to better assist these women.

It is possible that the results of this research will contribute to future research in other penitentiary institutions, which will be able to research women partners of inmates in other regions of Brazil, with different strategies of nursing practices and the insertion of other professionals in the prison environment aiming at the actions of health promotion and prevention for these women and their incarcerated partners.

\section{CONCLUSION}

The implications of this study legitimized the association of the types of risky and sexual behavior with chances for complications of abortion throughout life in women of inmates. These risk factors are closely linked to age under 30 , which is a non-modifiable risk factor, to smoking addiction, not using condoms, sexual violence and diagnosis or treatment of STI. It is noticeable that women with a relationship with a convicted partner are vulnerable to the occurrence of abortion compared to the rates of national studies with women in general, as this may be directly related to the different factors and behaviors in this population that may be associated with occurrence of abortion.

Therefore, the needs of the nursing team, together with other health professionals, work with a view to creating a greater bond with this population with information transfer and sensitization regarding the complications of abortion and the factors that may be associated with it. It is important to emphasize the importance of thinking about the healthdisease-care process beyond the incarcerated individual, thus involving an expanded network to include the woman of the inmate in the National Policy to People Deprived of Liberty, within the territory of the Family Health Strategy program and in the Comprehensive Women's Health Care Policy.

It is important to highlight that there are some limitations of the study and need to be considered. We highlight that the cross-sectional design did not allow inferences about temporal relationships or causal paths between variables. Also, by relying on self-report data, the findings may have been affected by the social convenience bias of women of inmates, the results may not be generalizable to other 
women with normal lifestyles. Another important highlight is that, due to time and space limitations, we did not collect broader information on current use and history of contraception, the gestational age for abortion was not verified, nor the history of spontaneous or induced abortion. Finally, risk factors may differ between married and unmarried women, but the sample size provided adequate statistical power to analyze and identify the prevalence and possible risk factors associated with abortion among women of inmates.

\section{QREFERENCES}

1. Barbosa DCM, Furman GR, Santos AL, Molena-Fernandes CA. Depression in the wives of convicted men: prevalence and associated factors. Rev Bras Enferm. 2017;71(Supl 1):538-45. doi: https://doi.org/10.1590/0034-7167-2017-0263

2. Martins DC, Pesce GB, Silva GM, Fernandes CAM. Sexual behavior and sexually transmitted diseases among the female partners of inmates. Rev Latino-Am Enfermagem. 2018;26:e3043. doi: https://doi.org/10.1590/1518-8345.2568.3043

3. Cardoso BB, Vieira FMSB, Saraceni V. Abortion in Brazil: what do the official data say? Cad Saúde Pública. 2020;36(Supl 1):e00188718. doi: https://doi. org/10.1590/01002-311x00188718

4. Ganatra B, Tunçalp Ö, Johnston HB, Johnson Jr BR, Gülmezoglu AM, Temmerman M. From concept to measurement: operationalizing WHO's definition of unsafe abortion [editorial]. Bull World Health Organ. 2014;92:155. doi: http://doi. org/10.2471/BLT.14.136333

5. Diniz D, Medeiros M, Madeiro A. National abortion survey 2016. Ciênc Saúde Colet. 2017;22(2):653-60. doi: https://doi.org/10.1590/1413-81232017222.23812016

6. Souza MG, Fusco CLB, Andreoni AS, Silva RS. Prevalence and sociodemographic characteristics of women with induced abortion in a population sample of São Paulo, Brazil. Rev Bras Epidemiol. 2014;17(2):297-312. doi: http://doi. org/10.1590/1809-4503201400020002ENG

7. Sullivan GP, Guédou FA, Batona G, Kintin F, Béhanzin L, Avery L, et al. Overview and factors associated with pregnancies and abortions occurring in sex workers in Benin. BMC Womens Health. 2020;20:248. doi: https://doi.org/10.1186/ s12905-020-01091-6

8. Szucs LE, Lowry R, Fasula AM, Pampati S, Copen CE, Hussaini KS, et al. Condom and contraceptive use among sexually active high school students - youth risk behavior survey, United States, 2019. MMWR Suppl. 2020;69(1):11-18. doi: https://doi.org/10.15585/mmwr.su6901a2

9. Bassani F. Amor bandido: cartografia da mulher no universo prisional masculino. Dilemas. Rev Estud Conflito Controle Soc. 2011 [cited 2020 Sep 10];4(2):261-80. Available from: https://revistas.ufrj.br/index.php/dilemas/article/view/7225/5813. pdf

10. Ministério da Saúde (BR). Portaria Interministerial no 1, de 2 de janeiro de 2014. Institui a Política Nacional de Atenção Integral à Saúde das Pessoas Privadas de Liberdade no Sistema Prisional (PNAISP) no âmbito do Sistema Único de Saúde (SUS). Diário Oficial União. 2014 jan 3 [cited 2020 Mar 10];151(2 Seção 1):1821. Available from: https://pesquisa.in.gov.br/imprensa/jsp/visualiza/index. jsp?data $=03 / 01 / 2014 \&$ jornal $=1 \&$ pagina $=18 \&$ totalArquivos $=72$
11. Ministério da Justiça (BR). Departamento Penitenciário Nacional. Levantamento nacional de informações penitenciárias: atualização - junho de 2016 [Internet]. Brasília, DF: Ministério da Justiça, 2016 [cited 2020 Feb 20]. Available from: http://antigo.depen.gov.br/DEPEN/depen/sisdepen/infopen/Infopenjun2016. pdf

12. Abdo CHN, Oliveira JrWM, Moreira ED, Fitipaldi JAS. Perfil sexual da população brasileira: resultado do Estudo do Comportamento Sexual (ECOS) do Brasileiro. Rev Bras Med. 2002 [cited 2020 Mar 10]; 59(4):250-57. Available from: https:// www.arca.fiocruz.br/handle/icict/19449

13. Yanyan $D$, Hongbo $Z$, Yongyang W, Haidong T, Song $X$, Junrui $X$, et al. Multiple abortions and sexually transmitted infections among young migrant women working in entertainment venues. Women Health. 2015;55(5):580-94. doi: https://doi.org/10.1080/03630242.2015.1022811

14. Bell SO, Omoluabi E, OlaOlorun F, Shankar M, Moreau C. Inequities in the incidence and safety of abortion in Nigeria. BMJ Glob Health. 2020;5:e001814. doi: https:// doi.org/10.1136/bmjgh-2019-001814

15. Brêtas JRS, Zanatta LF, Moraes SP, Freitas MJD, Goellner MB. Conhecimentos e opiniões de adolescentes sobre abortamento. Rev Aten Saúde. 2017;15(53):20-7. doi: https://doi.org/10.13037/ras.vol15n53.4654

16. Mello PRB, Pinto GR, Botelho C. Influência do tabagismo na fertilidade, gestação e lactação. J Pediatr. 2001 [cited 2020 Feb 15];77(4):257-64. Available from: http://www.scielo.br/pdf/jped/v77n4/v77n4a06

17. Santos JN, Souza EFM, Aquino AP, Santos JN, Bissaco DM, Suano ER, et al. A orientação de enfermagem em gestantes que fazem uso do álcool e tabaco. Rev Recien. 2014;4(10):5-11. doi: https://doi.org/10.24276/ rrecien2358-3088.2014.4.10.5-11

18. Vu GV, Ngo CQ, Phan PT, Doan LPT, Nguyen TT, Nguyen MH, et al. Inadequate knowledge, attitude and practices about second-hand smoke among non-smoking pregnant women in urban Vietnam: the need for health literacy reinforcement. Int J Environ Res Public Health. 2020;17(10):3744. doi: https://doi.org/10.3390/ ijerph17103744

19. Cooper HLF, Caruso B, Barham T, Embry V, Dauria E, Clark CD, et al. Partner incarceration and African-American women's sexual relationships and risk: a longitudinal qualitative study. J Urban Health. 2015;92(3):527-47. doi: https:// doi.org/10.1007/s11524-015-9941-8

20. Martins DC, Teston EF, Dobiesz BA, Fernandes CAM, Marcon SS. Sexual and health behavior among women of convicts: na exploratory study. Online Braz J Nurs. 2018;17(1):43-53. doi: https://doi.org/10.17665/1676-4285.20185864

21. Machado CL, Fernandes AMS, Osis MJD, Makuch MY. Gravidez após violência sexual: vivências de mulheres em busca da interrupção legal. Cad Saúde Pública. 2015;31(2):345-53. doi: http://doi.org/10.1590/0102-311X00051714

22. Mason F, Lodrick Z. Psychological consequences of sexual assault. Best Pract Res Clin Obstet Gynaecol. 2013;27(1):27-37. doi: https://doi.org/10.1016/j. bpobgyn.2012.08.015

23. MaranhãoTA, Gomes KRO, Barros IC. Predictive factors of abortion among teenagers with obstetric experience. Rev Bras Epidemiol. 2016;19(3):494-508. doi: https:// doi.org/10.1590/1980-5497201600030003

24. Ko CM, Koh CK, LeeYS. An ethical issue: nurses'conscientious objection regarding induced abortion in South Korea. BMC Med Ethics. 2020;21:106. doi: https://doi. org/10.1186/s12910-020-00552-9 
Martins DC, Silva GM, Ribeiro BMSS, Pesce GB, Fernandes CAM

\section{- Authorship contribution:}

Conceptualization, Data curation, Methodology and Resources: Débora Cristina Martins.

Data curation and Writing-original draft: Giovana Brichi Pesce.

Investigation, Formal analysis, and Writing-original draft: Beatriz Maria dos Santos Santigo Ribeiro.

Investigation, Data curation, Writing-original draft:

Giordana Maronezi da Silva.

Conceptualization, Methodology, Software, Writing-

review \& editing: Carlos Alexandre Molena Fernandes.

The authors declare that there is no conflict of interest.

\section{- Corresponding author:}

Débora Cristina Martins

E-mail: martinsdebora344@gmail.com

\section{Editor-in-chief:}

Maria da Graça Oliveira Crossetti 